Available online at http://jgu.garmian.edu.krd

Journal of University of Garmian

https://doi.org/10.24271/garmian.196223

\title{
An Investigation into the Problems of Translating English Modal Auxiliary verbs as used by Kurdish EFL Learners
}

\author{
Hazha Hiwa Mohammad and Dr. Hoshang Farooq Jawad \\ English department, College of Basic Education,University of Sulaimani
}

\section{Article Info}

Received: May, 2019

Revised: June,2019

Accepted: June,2019

\section{Keywords}

Translating. Kurdish EFL, Modal Auxiliary

\section{Corresponding Author}

aveen.hidayat@garmian.edu.krd

\begin{abstract}
This study entitled "An Investigation into the Problems of Translating English Modal auxiliary verbs as used by Kurdish EFL learners" attempts to investigate the problem of translating English modal auxiliaries by fourth-year students in the English departments at the university level.The study aims to explore the most common problems in translating modal auxiliaries that face Kurdish EFL students at university level. It also seeks to find out whether these problems stem from the inherent semantic features of the modals or not, as well as determining the best translation strategies to overcome the difficulties.The study hypothesizes that Kurdish EFL learners encounter problems during translating modal auxiliaries and that translation problems of modals stem from the inherent semantic features. Moreover, Kurdish EFL learners must consider translation strategies and techniques to overcome the difficulties.

Finally, the study concludes that, modal auxiliary verbs in English and their shades of meaning bring serious difficulties for Kurdish EFL learners, and the students are not knowledgeable about using translation strategies. Thus, they face great number of problems such us linguistic, grammatical, equivalence, and structural difficulties.
\end{abstract}

\section{Introduction}

Modal auxiliaries are auxiliary verbs, which are attached or connect together as a closed group. Moreover, they share two main characteristics of forms together; first modal auxiliaries do not take an -s in the third person singular for the present tense form. For example, (he can) not (he cans). Second "they do not have the participle form, present or past" (Stagaberg \& Oaks, 2000, p.188). And according to (Biber, Johansson, Leech, Conrad, and Finegan, 1999) English language has nine central modal auxiliary verbs that are used to express modality (can, could, may, might, shall, should, will, would, must).
In addition, modal auxiliaries can tell us "how certain or uncertain we are" (Eastwood, 2005, p. 101) or help us to allow and say things to people to do. Furthermore, modal auxiliary verbs precede a verb stem and give them certain appropriate shades of meaning, like volition, probability, Futurity, permission, possibility, and necessity. In such a manner, they mark the verb they follow, thus because of this characteristic they are called verb marker (Stagaberg, 1981).

However, the central modal auxiliary verbs are not formally distinguished for tense, and they "can be used to make time distinction" 
(Biber et al., 1999, p.484) for instance we have modals that can be used exclusively for a future time (will and shall):

1. We shall connect with these members.

Hence, according to Biber et al. (1999); Greenbaum \& Nelson (2009); Stagaberg \& Oaks (2000) most of the modals (except 'must') demonstrate a "tense distinction between past and present". It means that in a special context or in limited circumstances, they can individualize between past and nonpast time, and they divided modals into two parts, the second part is the past tense of the first four pairs:

$\begin{array}{lc}\text { Can } & \text { could } \\ \text { May } & \text { might } \\ \text { Shall } & \text { should } \\ \text { Will } & \text { would } \\ \text { 2. } & \text { I think I can help you. } \\ \text { 3. } & \text { I thought I could help you. }\end{array}$

However, they have a lot of distinct meanings that we can make by these pairs of modals with their main function, especially those that are associated with the pastime. For example, they have a connection with a hypothetical situation, conveying overtones tentativeness and politeness, for this reason, and according to Stagaberg \& Oaks (2000) modal auxiliary verbs "are expressing delicate nuances of meaning exclusive of time" (p.189) due to these examples:
4. May I help you?
5. Might I help you?
6. Can I help you?
7. Could I help you?
8. You must be careful.
9. Will you came again?
10. Would you came again?
11. Shall I return it?
12. Should I return it?
13. You ought to be careful.

Generally, and overall, the meanings expressed are many and brilliantly shaded.

\section{Mood and Modality}

According to Finch, mood or modality refers "to the way in which the verb expresses the attitude of the ADRESSER towards the factual content of what being communicated" (2000, p.103). However, Stagaberg and Oaks describe mood by corresponding to the form of a verb by telling us "about an attitude of the speaker in relation to what is being said" (2000, p.156). Furthermore, Palmer says, "Modality is concerned with the status of the proposition that describes the event." (2001, p. 1). He made a "binary distinction" to analyze modality between "non-modal" and "modal" or "declarative" and "non-declarative", to refer to this distinction with the notional contrast of "factual" and "non-factual", or "real" and "unreal".

Mithun (1999) argues that the distinction between realis and irrealis depends on how the situations are portrayed; whether the situations are really existent (realis) or only we imagine those situations (irrealis) (as cited in Palmer, 2001, p.1). Thus, realis and irrealis are two semantic types of modality, while modality can be expressed morphologically by mood. In fact, we notice a differentiation between the categories of different languages that are treated as realis and irrealis, while in Eng lish language modal verbs are used to distinguish between propositions from a categorical statement:

14. Soma is in hospital.

15. Soma may be in hospital.

16. Soma must be in hospital.

Crystal (2008) distinguishes three types of mood: indicative, imperative, and subjunctive. Indicative is for indicating actual meaning, and combines with the two sub-types: declarative and interrogative (finch, 2000):

17. We are doing the homework this morning.

18. Are we doing the homework this morning? Though the imperative mood is for expressing directive utterances with excluding the subject (i.e. ordering or requesting someone to (not to do) or to do something) (Crystal, 2008).

19. Open the book. 
20. Please, close the book.

The last type is the subjunctive mood, which is the least used in the English language. Quirk and Greenbaum (1973) distinguished three different categories of the subjunctive.

\section{A) The Mandative Subjunctive}

The Mandative subjunctive is used with thatclauses and indicated by the use of the base form of the verb with third person singular, it means that there is lack of concord between subject and verb, while the main clause expresses a request, recommendation, demand, etc....

21. Nada recommended that she leave immediately.

22. He suggested that the house be rewired.

B) The Formulaic Subjunctive

The formulaic subjunctive is also used the base form of the verb and it is used in the idiomatic expression:

23. Be that as it may...

24. Heaven forbid!

25. Come what may, we will go ahead.

26. God save the Queen!

C) The Subjunctive that expresses wishes or conditions

The subjunctive mood is used to indicate and express a wish or it is used in conditional clauses, but while expressing the condition often the clause starts with if, as if or as though. Moreover, it is indicated by the use of were instead of was with singular subjects.

27. I wish I were you.

28. She pretended as if she were guilty.

All languages deal with grammatical categories differently, but for the category of modality, there are two ways, in terms of the modal system and mood. While we may have both in a single language, like in German; however, most languages have only one devise, or one of them more noticeable or important than the other, for instance, the subjunctive going to be disuse in some European languages. "While in the English language it has virtually disappeared and, at the same time, a modal system of modal verbs has been created" (Palmer, 2001, p.4)

\section{Meaning of Modal Auxiliaries}

Modal auxiliaries are used to express writers or speaker's idea, view, attitude or opinion when they want to express a possible fact or to control a possible action (Hykes, 2000).

According to (Greenbaum \& quirk, 1990) modal auxiliaries can be differentiated and divided into two main types of meanings:

1- INTRINSIC modality: (also called deontic meaning) the speaker or writer 'directs' or control the action, i.e. Hu mans have the power to direct events, and they give and refuse permission. They talk about obligation and necessity. (The subject usually refers to a human being and the main verb usually is a dynamic verb.) Accordingly, meaning relating to permission, obligation, and volition.

29 You may eat now. (I give you permission to eat now)

30. You must read the newspaper at once. (I require you to read ....)

31. I could swim when I was young. (I knew how to swim.)

2- EXTRINSIC modality: (epistemic meaning) the speaker or writer anticipates or figures out the fact, and they judge how a certain thing is or is not likely to happen. Moreover, "refer to the logical status of events" (Biber et al., 1999, p.485), and also, unlike intrinsic meaning, the subject is a nonhuman and usually the main verb refer to those verbs that they have stative mean ings. In addition, the meaning of this type usually relating to a possibility, necessity, and prediction.

32. They may be pass from the exam. (It is possible that they are pass from the exam.)

33. You must be feeling tired. (It is certainly obvious from your face.)

34. That could be your sister. (It is possible that it is...) 
While according to Palmer, Dynamic modality will be the third kind of modality meaning and it refers to the subject itself neither attitude nor opinion rather than it deals with "the ability or volition of the subject of a sentence." (1990, p. 36).

Modal auxiliaries according to their main meaning sorted and divided into three major categories (Biber et al., 1999):

Permission, possibility, ability: can, could, may, might

Obligation, necessity: must, should

Volition, prediction: will, would, shall

Using modal auxiliaries is complex and more problemat ic because of their distinct meanings that "involve both a logical (semantics) and a practical (pragmatic) element." (Leech, 2004, p.114) and of course social and psychological factors have influences over communication and according to their context, their meaning will be changed, however, Palmer informs us that the core meaning of modals commonly has to be deducted from the context (1990). Traditionally each modals have one meaning that is more common than others are, and their meanings are so close to each other. For instance, a sentence;

35. John may leave.

The speaker or writer may have one of these two distinct attitudes, either may be used to permission (deontic meaning), or for possibility attitude (epistemic meaning), therefore many linguists confirm that the modal auxiliaries are "systematically ambiguous" (Laird, 1978, p.18).

Lewis said that the modals are "one of the most complicated problems of the English verbs" (1986, p.99), although many linguists discuss this subject and announced them as "messy and untidy" like Palmer and Longman. However, above this complexity, there is a "large central area which is systematic and relatively easily understood." (Lewis, 1986, p.99).

\section{Translation}

Translation is a process of transferring spoken or written source language (SL) texts to equivalent spoken or written target language (TL) texts, the texts are of the various types, like religious, scientific, literary, and philosophical texts. Newmark defines translation as "it is rendering the meaning of a text into another language in the way that the author intended the text" (1988, p.5). Although translation and interpretation terms are used interchangeably, translation relates to the written language and interpretation to the spoken word in a rigid definition. However, according to Bukacek translation is a combination of language ability, in a process of decision-making like subject-specific knowledge, intuition, research skill, and judgment (2001). A variety of approaches are used for this process, in fact determining the suitable approach will be changed according to the personality and experience of a translator although it is essentially the type of document will determine which approach should be used for translating..

\section{Types of translation}

Linguist Roman Jakobson on his essay "On Linguistics Aspects of translation" (1959) distinguished three types of translation:

1. Intralingual translation or rewording (an interpretation of verbal signs by means of other signs in the same language).

2. Interlingual translation or translation proper (an interpretation of verbal signs by means of some other language).

3. Intersemiotic translation or transmutation (an interpretation of verbal signs by means of signs of nonverbal sign systems).

The intralingual translation "is an interpretation of verbal signs by means of other signs of the same language. Intralingual translation can refer to rewording or paraphrasing, summarizing, expanding or commenting within a language." (Mirzayeva, n.d., p.1). Some translation scholars argue that the definition of translation should not contain 
an intralingual translation, and they only pay attention to interlingual translation.

In contrast, interlingual or proper translation is a process of transferring SL to TL (I.e. translation between any pair of human languages). Of course, this is not an easy process, because translator should try hard to find an adequate equivalent in the target language. Although those words that have more than one meaning (polysemy) always make problems for the translator, therefore the translator should be careful about the context and being sure to which means the word is used (da Silva, 2017).

Intersemiotic translation is the third type of translation that outlined by Jakobson (1959), which deals with transferring between sign systems and media that are commonly used in visual arts film, theater, and in designing advertising. Thus translating any individual work like a film, a book, etc. to a different form of textuality or media platform or vice versa is an intersemiotic translation.

Nevertheless, Jakobson describes the major problem of all types: that although the messages can function as satisfactory interpretations of code units, there is usually no full equivalence in translation. Indeed the appropriate synonymy does not yield equivalence. In addition, Jakobson as cited in (Bassnett, 2014, p. 25) discusses "how intralingual translation often has to resort a combination of code units in order to fully interpret the meaning of a single unit"

\section{Strategies of Translation}

Translation's strategies were discussed and suggested by different scholars that are classified it according to their particular perspectives. Including Chesterman who categorized local translation strategies into syntactic, semantic, and pragmatic changes, that each one of them has its own subcategories without any obvious distinction between them. Lorscher also identified nine elements as building blocks of translation strategies. Moreover, Vinay and Darbelnet were differentiating between two main methods of translating, direct/literal translation and oblique translation, and then they talked about seven subcategories of oblique translation as strategies for translation. Nevertheless, the most applicable set of strategies offered by Mona Baker as taxono my of translation's strategies, which are used by professional translators (Owji, 2013).

Baker discussed eight strategies that are used by a professional translator (1992):

1. Translation by a more general word Baker believes this is one of the most common strategies for dealing with many types of nonequivalence, especially in the meaning area, the structure of the semantic field is not dependent on a specific language, and it works uniformly in most, if not all, languages.

2. Translation by a more neutral/ less expressive word

This is another strategy deals with those words or phrases that are difficult to translate, less expressive in most languages because they have no direct or near equivalent in the semantic field of the structure.

3. Translation by cultural substitution This strategy involves replacing a culturespecific item or expression with a target language item considering its impact on the target reader. This strategy helps the reader of the target language more familiar and appealing text more natural, and understandable.

The translator's decision to use this strategy will depend on:

a. The degree to which the translator is given license by those who commission the translation.

b. The purpose of the translation.

4. Translation using a loan word or loan word plus an explanation

This strategy is often used in dealing with culture-specific items, modern concepts, and buzzwords. Coming to the loanword with an explanation is very useful when in the text a word is repeated for several times. For the first time, the word comes with the explanation and 
in the next times, the word can be used by its own.

5. Translation by paraphrase using a related word

This strategy is used when the source item is lexicalized in the target language but in a different form, and when the frequency with which a certain form is used in the source text is obviously higher than it would be natural in the target language.

6. Translation by paraphrase using unrelated words

The paraphrase strategy can be used in some contexts when the concept in the source item is not lexicalized in the target language. In particular, if the meaning of the source item is complex in the target language, the paraphrasing strategy may be used. Instead of using related words, it may be based on modifying a super-ordinate or simply on making clear the meaning of the source item.

\section{Translation by omission}

This strategy is a drastic kind; translators use this strategy to get rid of lengthy explanations, indeed, omitting some word or expression does not damage the text, if the meaning conveyed by a particular item or expression is not necessary to mention in the understanding of the translation.

\section{Translation by illustration}

In some context the target language lacks equivalent word, Thus this strategy will be useful especially when the target item does not cover some aspects of the source item and the equivalent item refers to a physical entity which can be illustrated, so in order to be concise and to the point, the translator must avoid over-explanation.

\section{Translation problems of modals}

The concept of modality varies from one language to another, therefore the meaning of modality depending on a single perspective is very difficult to determine. Translating modal auxiliaries from English into Kurdish and vice versa imposes many difficulty and problems for the translator:

1-In a special context 'shall' is used in the meaning of obligation instead of referring to the future, particularly in the language of law. For solving this problem 'shall' means 'must' in all English legal texts. Moreover, 'should' is also used in the meaning of 'must' while usually many students understood 'should' as the past tense of 'shall' (referring to the future in the past tense) for solving this 'should' is always translated to 'must'( Ghazala, 1995).

36. You should look at him.

37. We should listen to our parents.

38. I should say everything.

39. You must leave now.

40. You may leave now.

In example 39 'must leave' expresses deontic necessity (obligation), while 'may leave' in 40 means deontic necessity (permission). Consequently, in the Kurdish language, we have the same situation, therefore till here all is clear, but if we replace (you) with (he) the sense of modals will change to ambiguous. Thus it imposes the problem for the translator to determine between a sense of ability, possibility, and permission, as cited in (AbdelFattah, n.d., p. 3) Suzuki (1986) argues that ambiguity "among the root senses of modals have much to do with their related backgrounds. It is because there is much confusion as to whether the speaker is referring to permission or some other ... type of situation in the background that ambiguous sentences ... come about."

Determining the exact meaning of modals in terms of their logical categories epistemic, deontic, dynamic with the notions expressed by them is difficult. Therefore Leech and Coates (1980) as cited in (Abdel-Fattah, n.d., p. 3) mention this issue as "semantic indeterminacy", which the meaning expressed by modals cannot easily differentiate. Thus Leech identifies three types of indeterminacy:

A. Ambiguity: where more than one interpretation is possible; two or more meanings, e.g. 
41. He must understand that we mean business.

(Epistemic/deontic interpretation of necessity)

42.I couldn't sleep that night.

(Dynamic ability/deontic permission)

Under this category, we usually select one meaning. (Either/or relationship)

Merger: where we have two interpretations bearing mutual meanings. Usually, both meanings are possible; whichever meaning is used, the sentence makes sense in roughly the same way (both/and relationship).

43. You can go home now.

(Possibility/permission)

44. Yes, I've finished. You can leave now.

(Possibility/permission)

C. Gradience: where two meanings exists e.g. possibility, permission, between which we have intermed iate cases that cannot be clearly assigned between them.

45. You can't do that.

Possible meanings:

- I forbid it.

- It would be breaking the law.

- It is against the rules.

- It is not right.

- They'll think you are mad.

- It is not reasonable.

- It is non-ethical.

- It is against your religion. etc.

46. Must that you go to the mosque.

Possible meanings:

a. pray

b. meet someone

c. work

d. see what is going on

e. participate in a meeting etc.

Ghazala (1995) mentions two major problems in translating modals, which is first, the unclear meaning of 'might', 'could', 'would' and understood as the past tense of 'may', 'can', 'will' when used with distinct mean ings in the present simple: they have the common use in the meaning of permission, possibility, and expression of politeness/request, therefore they have the sense of 'may':

47. She could blame herself.
48. She would blame herself.

49. She might blame herself.

They represent the grammatical functions of expressing possibility, permission and polite request; therefore, it is not possible to translate them as the verbs in the past.

Second: 'can', 'will', 'may' are equivalent to 'could', 'would', 'might' in the sense of 'may' and they are interchangeable, that is why usually the confusion occurs. However the common meaning of 'will' is the future tense and 'can' express ability, but also they are used to express a polite request:

50. Can you open the door?

51. Will you open the door?

52. May you open the door?

In addition, both 'can' and 'may' are used to express possibility and/or permission:

53. You can open the door.

54. You may open the door.

\section{Data Analysis}

\section{Introduction}

The data analysis deals with the students' translation for texts which contain modal auxiliaries. First, the researcher puts the original texts one by one and each one is followed by a correct translation into Kurdish, which is used as the model for the students' translation. Second, choosing which modal is translated correctly and incorrectly by the students and putting them in a table, after this differentiation, the most wrongly translated modal is analyzed so as to realize what the problem is and how we can find the solution.

Text (1)

"A weather system that gained strength Wednesday in California will become a powerful six-day, coast-to-coast storm - one that's forecast to roar all the way from the Southwest to the mid-Atlantic....In southern Texas, heavy rain and thunderstorms could lead to dangerous flash flooding. Some of the storms may become strong enough to produce damaging wind gusts and isolated tornadoes" (USA TODAY) 
بارى كمشو هدواى كاليفوّرنيا له رِوّرى جوارشهمهوه بوّ ماوهى شهش

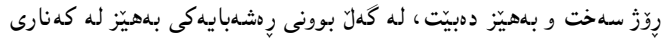

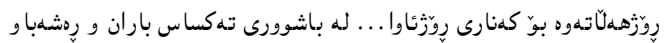

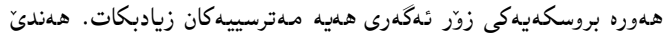

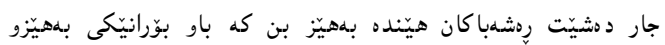

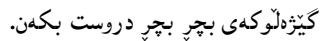

Most students have translated 'could' in the wrong way, instead of 'ئدكدى هديه' they understood it as the past tense of 'can'. We assume that this incorrect translation is due to the old belief that whenever 'could' is used, it is for denoting the ability in the past. The best strategy to render this modal into Kurdish is 'translation by paraphrase using a related word'.

Text (2)

"Speaking at a parliamentary press gallery lunch, Blair said that MPs could be obliged to consider a second referendum. 'My guess, and I may be $100 \%$ wrong, is that when all the options are voted upon, parliament will come to the view that none can truly be said to reflect the majority will of the people, and it's back to them therefore that we must go for resolution.'" (The Guardian)

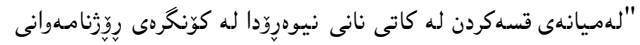

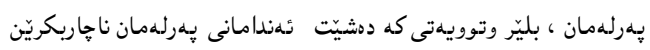

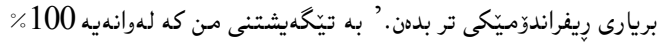

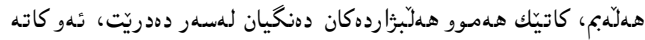

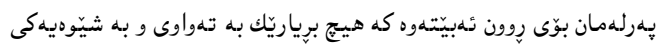

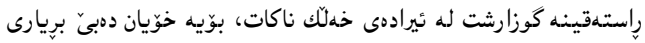

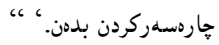

Most of the students translate 'could' into 'دوانديتت' 'instead' and 'can' into 'دوانراوه' which are wrong, we consider that these incorrect translations first for 'could' is due to the common mistake for 'could', 'would', and 'might' that understood usually as the past tenses for 'can', 'will', and 'may'. And also confusion between 'can' and 'may' is more obvious here. Moreover, the best strategy to render 'could' into Kurdish is 'translation by paraphrase using a related word' while for rendering 'can' 'omission' is the best one.
Text (3)

How the U.S. uses international networks to enhance its power

"Air transport has developed centralized patterns of transportation to lower costs. Passengers fly through 'hub' airports, where they must make connections to get from one destination to another." (The Washington post)

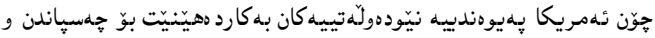

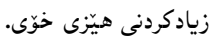

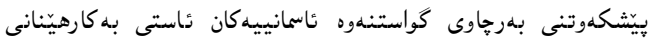

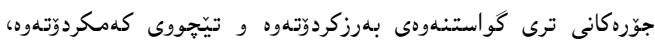

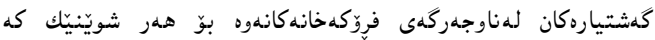

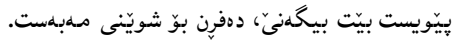

Most students have translate 'must' into 'بيانهويتّ' which is incorrect, and only three of them translated correctly into 'بيّويست'. We assume that this incorrect translation is due to, the students are not sure and confusing about translating 'must' between whether it's the great need 'necessity' or it's only the willingness. Thus, the best strategy to render 'must' into Kurdish is 'translation by a more general word'.

Text (4)

"On Saturday, portions of Arkansas and Missouri will see the threat of ice. A huge chunk of the South - all the way from Texas to the Carolinas - will see a soaking rain and a chance for flooding on Saturday....The storm could have some impact on the big cities of the mid-Atlantic and Northeast, but its exact track and potential snowfall amounts cannot be predicted yet." (USA TODAY)

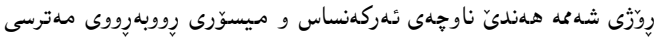

$$
\begin{aligned}
& \text { بهستن دمبنهوه. بهشيّكى زوّرى باشوور - هـر للهتهكساسهوه بوّ }
\end{aligned}
$$

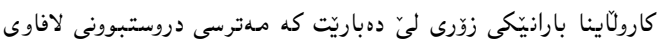

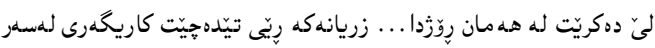

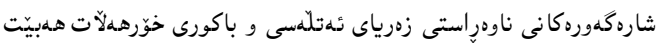

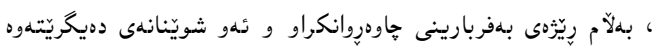

$$
\begin{aligned}
& \text { يِيَشبينى نهكراوه. }
\end{aligned}
$$


Most of the problems happen when the students have translated 'could'; this is because in the text 'could' is originally used for saying it is possible for the storm having some impact on the big cities 'رِيتيتيدهِجيَّ', but they translate could into 'توانيويةتى' which is incorrect. And also half of them have

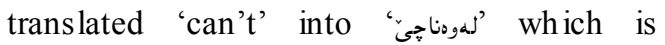
incorrect, we assume that this incorrect translation is due to 'may' and 'can' that are used for possibility and both can have the same meaning in some contexts, that is why these confusion happen. Moreover, the best strategy to render 'can' into Kurdish is 'omission'.

Text (5)

"In September Labour adopted a compromise position in which the party would first decide whether to oppose May's deal, then, if it was voted down, try to force a general election, before turning to other options. But with the vote looming, Corbyn and the party's leadership is coming under pressure to spell out what it might do next" (The Guardian).

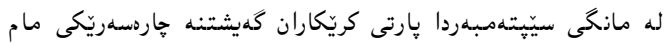

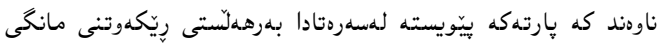
مدى بكات يا نا، دواى ئهوه ئه كهر له دزى دهنح درا ، هدولّ بدات

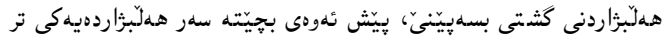

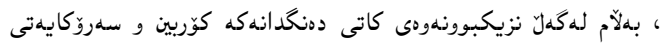

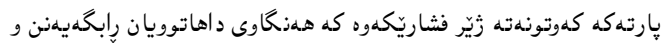

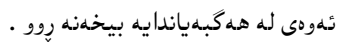

Most students have translated both modals in the wrong way, which are using 'would' for futurity instead 'بيّيويسته' and 'might' for a possibility instead 'ئدبيتي'. We assume that these incorrect translations are due to an understanding that, 'would' and 'might' are always the past tenses for 'will' and 'may'. In addition, the best strategy to render 'might' into Kurdish is 'omission'.

Text (6)
"Which is why Ada Hegerberg's speech at the Ballon d'Or ceremony on Monday was so powerful...that is not the first and will definitely not be the last time a female footballer experiences casual sexis $m$ at the highest level of the game, so we should probably identify the best way to deal with it.... It was a difficult moment all I could do at the time, live on air, was focus on my job and do it to the best of my abilities." (The Guardian)

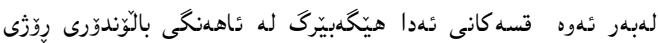

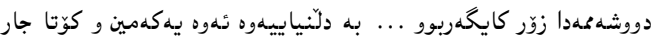
نابيّت كه ياريزانيّكى توَيى بِيِى ئافرهت رِووبهرووىى ئهزموونى جياكارى روكمزى لهبهرزترين ئاستيدا ببيّتهوه ، بوّيه بِيّويسته ئيّمه باشترين جارهسهر بوّ ئهم بابهته بدوّزينهوه ... ساتهوهختينكى سهخت بوو بوّ من هلهرئهوهندم يِيّكرا كه للهو كاتهداو له يهخشى راستتهوخو سهرنج بخهمه

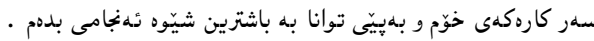

Most of the students have translated all three modals correctly; few of them translate incorrectly because here modals are used in common meaning. From that, we can conclude, even though they have some problem with common meaning but still, they can translate correctly.

\section{Conclusions}

In the light of the study findings and according to the results of the translation texts, modal auxiliary verbs in English and their shades of meaning bring serious difficulties for Kurdish EFL learners and the following conclusions can be drawn:

1. Students have learned that 'could', 'would', 'should', and 'might' are usually used as the past tenses for 'can', 'will', 'shall', and 'may'. For instance, they used 'could' for denoting the ability in the past. Moreover, they understood that these four modals cannot be used for the present tense.

2. According to the result of the translations, the students encounter a big problem in using 'Can' and 'may'; usually confuse and understood to mean the same, 
because in some contexts both can have the same meaning.

3. The students are not sure and become confused about translating 'must' between whether it is used for the great need 'necessity' or it's only referring to the willingness.

4. The students are good at translating modals when they are used in a common sense and are familiar to them. Although, sometimes they still have a problem, but if we compare it with other shades that are not a more common meaning, it is negligible.

5. According to the results, the students are familiar only with some meaning of modals that are overly used (like "ability" meaning of 'can') and some of them are not really used by the students (like the "possibility" meanings of 'can' and 'could').

6. The results of this study show that the students are not knowledgeable about using translation strategies. Thus, they face many kinds of problems such us linguistic, grammatical, equivalent, and structural difficulties.

7. Each one of modal auxiliaries has several shades of meaning either in English or in Kurdish and what is more, each meaning of them has a logical and pragmatic part.

8. The students cannot differentiate between the 'possibility' and 'ability' meanings of 'may' and 'might' in most contexts. Also, this problem recurs with 'can' and 'could'.

9. Most of the students whenever they come across 'should' they immediately translate it into an obligation; because an obligation is the strong shade of meaning for 'should', and ignoring that in some context 'should' refers to noncommitted necessity (i.e. the speaker is not sure, but based on his knowledge tentatively concluding that).

Recommendations

Based on the findings of the study, the following recommendations can be put forward:
1. In learning and teaching a second language, grammar and Translation are a very important component, and they include many problematic areas in terms of modal auxiliary verbs. Thus, it is very important to draw Kurdish EFL learner's attention to master all modals' shades of meaning, because they face many difficulties in translating them.

2. The students are recommended to familiarize themselves with translation strategies which are intended to tackle various translation problems.

3. We also advise teachers to teach translation strategies, and syllabus designer are also advised to in cooperate translation strategies into translation syllabi.

4. EFL teachers must familiar with the problems of modals that the students encounter, including a big confusion about whenever they face 'could', 'might', 'would', 'should' they translated as the past tense of 'can', 'may', 'will', 'shall'.

5. EFL teachers must select all using of modals due to students familiarize and not being confused between them.

6. Insisting on repeating modal auxiliaries throughout different levels is very important; due to the students grasp all meaning of modals entirely.

7. English modal auxiliaries could be taught in grammar and translation lessons.

8. More attention should be paid to noncommon meanings of modal auxiliaries.

\section{References}

1- Abdel-Fattah, M. M. (n.d.). On the Translation of Modals from English into Arabic and Vice Versa: The Case of Deontic Modality.

2- $\quad$ Baker, M. (1992). In other words a coursebook on translation.

3- Bassnett, S. (2014). Translation studies(Fourth ed.). New York: Routledge.

4- Biber, D., Johansson, S., Leech, G., Conrad, S., Finegan, E., \& Quirk, R. (1999). Longman grammar of spoken and written English (First ed.). Harlow (Essex): Longman. 
5- Bukacek, J. (2001). Getting Started:

A Newcomer's Guide to Translation and Interpretation. American Translator's Association Publication.

6- Crystal, D. (2008). Dictionary of Linguistics and Phonetics. Malden, MA: Blackwell Publlishing.

7- Da silva, A. C. (2017). On Jakobson's Intersimotic translations in Asterix comics. Comparatisimi,71-81.

8- Eastwood, J. (2005). Grammar finder. Oxford: Oxford University Press.

9- Finch, G. (2000). Linguistics terms and concepts. New York: St. Martins Press.

10- Ghazala, H. (1995). Translation As Problems And Solutions(Seventh ed.). Beirut: Dar Wa Maktabat Al-Hilal.

11- Greenbaum, S., \& Nelson, G. (2009). An introduction to English grammar (Third ed.). Harlow: Pearson / Longman.

12- Greenbaum, S., \& Quirk, R. (1990). A student's Grammar Of The English Language(Third ed.). Harlow, Essex: Longman.

13- Hykes, Jenny Marie, "A comparison of the use of modal verbs in research articles by professionals and non-native speaking graduate students" (2000). Retrospective Theses and Dissertations. 7929.

14- Jakobson, R. (1959). On Linguistic Aspects of Translation - full text.

15- Laird, P. J. (1978). The meaning of Modality. Cognitive Science: A
Multidisciplinary Journal,2(1), 17-26. doi:https://doi.org/10.1207/s 15516709cog020

1_2

16- Leech, G. N. (2004). Meaning and the English verb. London: Routledge.

17- Lewis, M. (1986). The Eng lish verb: An exploration of structure and meaning. Boston, MA: Thomson/Heinle.

18- Mirzayeva, A. (n.d.). Translation. INTERLINGUAL TRANSLATION AS THE MAIN TYPE OF TRANSLATION.

19- Newmark, P. (1988). A textbook of translation. New York, United State of America: Prentice Hall.

20- Owji, Z. (2013). Translation Strategies: A Review and Comparison of Theories. Translation Jornal,17, No. 1.

21- Palmer, F. R. (1990). Modality and the English modals(Second ed.). London: Longman.

22- -----, F. R. (2001). Mood and modality(Second ed.). Cambridge, United Kingdom: Cambridge University Press.

23- Quirk, R., \& Greenbaum, S. (1973).

A university grammar of english(Fifth ed.). London: Longman.

24- Stageberg, N. C. (1981). An Introductory English Grammar(Forth ed.). New York: Holt, Rinehart and Winston.

25- Stageberg, N. C., \& Oaks, D. D. (2000). An introductory English grammar(Fifth ed.). United State of America: Thms on Heinle. 
Table (1): (Translated by 7 students, 1 blank)

\begin{tabular}{ccc} 
Modals & Correct & Incorrect \\
\hline Will & 4 & 3 \\
Could & 2 & 5 \\
May & 4 & 3
\end{tabular}

Table (2): (Translated by 12 students)

\begin{tabular}{ccc} 
Modals & Correct & Incorrect \\
\hline Could & 4 & 8 \\
May & 9 & 3 \\
Will & 8 & 4 \\
Can & 4 & 8 \\
Will & 7 & 5 \\
Must & 7 & 5
\end{tabular}

Table (3): (Translated by 10 students)

Modals Correct Incorrect

Must

3

7

Table (4): (Translated by 10 students)

\begin{tabular}{ccc} 
Modals & Correct & Incorrect \\
& & \\
\hline Will & 7 & 3 \\
Will & 6 & 4 \\
Could & 3 & 7 \\
Can not & 5 & 5
\end{tabular}


Table (5) :(Translated by 8 students)

\begin{tabular}{ccc} 
Modals & Correct & Incorrect \\
\hline Would & 1 & 7 \\
Might & 3 & 5
\end{tabular}

Table (6) : (Translated by 7 students)

Modals

Should

Could
Correct 4

5

4
Incorrect

3

2

3 